\title{
Phenylalanine And Tryptophan Intake Of Hyperactive Children With Autism
}

\author{
Puspito Arum $^{1}$, Dahlia Indah Amareta ${ }^{1}$, Faridlotul Zannah ${ }^{1}$ \\ ${ }^{1}$ Clinical Nutrition, Jember State Polytechnic, Jember, East Java, Indonesia
}

\section{Article Info}

History:

Received : 11 Nov 2017

Accepted : 22 Dec 2017

Available : 31 Dec 2017

\begin{abstract}
Background: Hyperactive is behavior which demonstrates the attitude of more energy than normal behavior. Level of neurotransmitter dopamine and serotonin in the body may be the factor of this disorder behavior. Level of phenylalanine and serotonin were found high in hyperactive children with autism. Level phenylalanine in the brain shows that it is not changed into tyrosine so dopamine can not be form. Serotonin derived from an amino acid tryptophan.

Objective: To understand the association between phenylalanine and tryptophan intake to hyperactivity of children with autism.

Methods: A survey analytic research with cross sectional approach involving 20 subjects. Phenylalanine and tryptophan intake data was collected by Semi Quantitative-Food Frequency Questionnaire (SQ-FFQ), and hyperactivity disorder of child ren with autis m was measured based on DSM-IV guidelines.

Results: Eight (40\%) children had low hyperactivity, 9 (45\%) children had moderate hyperactivity, $2(10 \%)$ children had severe hyperactivity, and $1(5 \%)$ child had very severe hyperactivity. Mean phenylalanine intake was $4899.74 \mathrm{mg}$ $( \pm 1543.42)$ with maximum and minimum intake respectively $7735.42 \mathrm{mg}$ and $1843.88 \mathrm{mg}$. Tryptophan intake was $1153.91 \mathrm{mg}( \pm 384.99)$ with maximum and minimum intake respectively $1953.89 \mathrm{mg}$ and $367.69 \mathrm{mg}$. There was significant association between phenylalanine intake $(p=0,034 ; r=0,477)$ and tryptophan intake and hyperactivity ( $\mathrm{p}=0,026 ; \mathrm{r}=0,492)$.

Conclusion: There is an association between intakes of amino acid phenylalanine and amino acid tryptophan with hyperactivity of autistic children.
\end{abstract}

Keywords :

Autism, dopamine, hyperactive, phenylalanine, serotonin, tryptophan

\section{INTRODUCTION}

Hyperactive is behavior which demonstrates the attitude of more than normal behavior. ${ }^{1}$ About $6-7 \%$ of people aged 18 and under were estimated have Attention deficit hyperactivity disorder (ADHD), ${ }^{2}$ and the rates are more or less the same between countries. ${ }^{3}$ Its prevalence is diagnosed approximately three times more often in boys than in girls. ${ }^{4}$

* Corresponding author:

Puspito Arum

Telp./Fax: +62331-333532 / +620331-333531

E-mail:puspito_arum@yahoo.com puspito_arum@polije.ac.id
Level of neurotransmitter dopamine and serotonin in the body may be one of the factor of this disorder behavior. High level of phenylalanin and serotonin were found in hyperactive children with autis $\mathrm{m}$. In children with autis $m$ high level of phenylalanin causes amino acid phenylalanine can not be converted into amino acid tyrosine. Unalterable amino acid phenylalanine accumulates in the blood that reaches the brain. This leads to a mental disorder that includes autistic behavior. ${ }^{5}$ High level phenylalanin in the body show that it is not changed into tyrosin so dopamin can not be form. 
In children with autism there is an increase of serotonin levels in the brain by $30-40 \%$ of normal people. ${ }^{6}$ Serotonin derived from an amino acid tryptophan. ${ }^{2}$ Therapy which lowers serotonin levels to balance with dopamine levels can improve the response of children with autism, improve the speaking ability and affect behavioral disorders in children with autis $\mathrm{m}^{7}$

This research aimed to understand the relationship between phenylalanine and tryptophan intake and hyperactivity of child ren with autism.

\section{MATERIALS AND METHODS}

This study was an analytical study with cross sectional design. This research was conducted at Autistic Daycare in Patrang district, Jember. The subjects in this study were children with autism diagnosed with ASD using the criteria of the Diagnostic and Statistical Manual of Mental Disorders (DSM-IV). ${ }^{1}$

Variables of this study were phenylalanine intake, tryptophan intake and hyperactivity level. Phenylalanine and tryptophan intake were defined as the amount of phenylalanine and tryptophan that were consumed for the last month collected by Semi Quantitative Food Frequency Questionnaire (SQFFQ) from subject's mother. Hyperactivity level was defined as behavior which demonstrates restlessness attitude based on 7 hyperactivity symptoms in DSMIV guidelines that classified into 4 levels: low (score $<8$ ), moderate (score 8-14), high (score 15-21) and very high (score 22-28). Each symptom has 4 rating scale score, they were scored 1 for not at all, 2 for just a little, 3 for pretty much and 4 for very much. ${ }^{8}$ Teachers in a day care helped and did observvation and collected hyperactivity data.

This study had been reviewed and approved by KEPK (Komisi Etik Penelitian Kesehatan) Politeknik Negeri Jember. Informed consent to participate in this study was signed by subject's mother.

Rank Spearman test (with $\alpha 0.05$ ) had been used to analyze association between phenylalanine and tryptophan intake and hyperactivity.

\section{RES ULTS}

This study was conducted to understand the association between phenylalanine and tryptophan intake to hyperactivity of children with autism. Twenty children in Autistic Daycare in Patrang district, Jember who were participated in this study consist of 13 boys and 3 girls. They were aged 5-17 years old. Protein intake were108.8g $\pm 34.24,37.77 \mathrm{~g}$ and $169.42 \mathrm{~g}$ respectively for Mean $\pm \mathrm{SD}$, minimum and maximu $\mathrm{m}$ protein intake.
Table 1 describes the frequency distribution of hyperactivity level

\begin{tabular}{lcc}
\hline \multirow{2}{*}{ Hyperactivity level } & \multicolumn{2}{c}{ Frequency } \\
\cline { 2 - 3 } & $\mathbf{N}$ & $\mathbf{\%}$ \\
\hline Low & 8 & 40 \\
Moderate & 9 & 45 \\
Severe & 2 & 10 \\
Very Severe & 1 & 5 \\
\hline Total & 20 & 100 \\
\hline
\end{tabular}

Table 1. Frequency distribution of hyperactivity level

Table 2 describes phenylalanine and tryptophan intake of all subjects.

\begin{tabular}{cccl}
\multicolumn{1}{c}{ Intake } & Minimal & Maximal & Mean $( \pm$ SD $)$ \\
\hline Phenilalaniane & $1843.88 \mathrm{mg}$ & $7735.42 \mathrm{mg}$ & $4899.74 \mathrm{mg}$ \\
& & & \pm 1543.42 \\
Tryptophan & $367.69 \mathrm{mg}$ & $1953.89 \mathrm{mg}$ & $\begin{array}{l}1153.91 \mathrm{mg} \\
\pm 384.99\end{array}$ \\
\hline
\end{tabular}

Table 2. Phenylalanin and Tryptophan Intake

This study revealed that there was relationship between phenylalanine intake and hyperactivity $(\mathrm{p}=0.034 ; \mathrm{r}=0.477)$ and there was relationship between tryptophan intake and hyperactivity $(\mathrm{p}=0.026 ; \mathrm{r}=0.492)$.

\section{DISCUSS ION}

Autistic disorders and its symptoms like hyperactivity are associated with conditions that have neurological lesions, especially rubella, phenylketonuria, tuberous sclerosis and Rett disorders. ${ }^{1,9}$ In children with autism high level of phenylalanine causes amino acid phenylalanine can not be converted into amino acid tyrosine. Unalterable amino acid phenylalanine accumulates in the blood that reaches the brain. This leads to a mental disorder that includes autistic behavior. ${ }^{5}$ The more amount of phenylalanine in the blood, the more it will accumulated in the brain. Accumulated phenylalanine in the brain affects the levels of dopamine in the brain, so that influence behavior and mental of autistic children. 5,10

The direct precursor of dopamine, L-DOPA, can be synthesized indirectly from the essential amino acid phenylalanine or directly from the non-essential amino acid tyrosine. ${ }^{11}$ These amino acids are found in nearly every protein and so are readily available in food, with tyrosine being the most common. Although dopamine is also found in many types of food, it is incapable of crossing the blood-brain barrier that surrounds and protects the brain. ${ }^{12}$ It must therefore be synthesized inside the brain to perform its neuronal activity. $^{12}$

Since the phenylalanine cannot be converted into tyrosine, it causes reduction of blood tyrosine amount. 
Little amount of tyrosine can reduce the production of dopamine which causes children show difficulty to concentrate, focus and hyperactivity. ${ }^{9,13}$

While dopamine comes from tyrosine, serotonin is derived from tryptophan. Increase of blood serotonin level were found in autistic children. ${ }^{7}$ Serotonin is synthesized from several enzy matic processes by the first process starting with tryptophan hydroxylase. ${ }^{14}$ Serotonin effect on behavioral disorders in people with autism. Thus the decrease of serotonin can help decrease autistic behavior disorder). ${ }^{5}$ Restricted intake of tryptophan will decrease serotonin levels in the blood. This is because the concentration of tryptophan in the body is an important substrate as a precurs or of serotonin formation. ${ }^{15,16}$

\section{CONCLUSION}

There is a relationship between intake of amino acid phenylalanine and amino acid tryptophan with hyperactivity of children with autism.

\section{ACKNOWLEDGEMENT}

We thank all of the subjects and their mothers for their participations. We thank Autistic Daycare in Patrang District, Jember and all of teachers for their contributions.

\section{REFERENCES}

1. American Psychiatric Association. (2013). The Diagnostic and Statistical Manual of Mental Disorder, Fifth Edition. Arlington: American Psychiatric Association.

2. Willcutt, EG. (2012). The Prevalence of DSM-IV Attention-Deficit/Hyperactivity Disorder: A MetaAnaly tic Rreview. Neurotherapeutics. 9 (3): 490-499.

3. Faraone, SV. (2011). Epidemiology of Attention Deficit Hyperactivity Disorder. In Tsuang, MT; Tohen, M; Jones, P. Textbook of Psychiatric Epidemiology (3rd ed.). John Wiley \& Sons.

4. Singh, I. (2008). Beyond Polemics: Science and Ethics of ADHD. Nature Reviews Neuroscience. 9 (12): $957-$ 964.

5. Kessick R. (2011). Autisme dan Pola Makan yang Penting untuk Anda Ketahui. Jakarta : PT Gramedia Pustaka Utama.

6. Puspaningrum, Christine. (2010). Pusat Terapi Anak Autis di Yogyakarta. Graduate Thesis. Atma Jaya University, Yogy akarta.
7. Wardhani, Fauziah Y, Prabaningrum V, Kirstiana L. (2009). Apa dan Bagaimana Autisme Terapi Medis Alternatif. Jakarta : Fakultas Ekonomi Universitas Indonesia.

8. Brock, S. E., \& Knapp, P. K. (1996). Reading comprehension abilities of children with AttentionDeficit/Hyperactivity Disorder. Journal of Attention Disorders. 1: 173-185

9. Kurniawan, Liong Boy. (2015). Patogenesis, Skrining, Diagnosis, dan Penatalaksanaan Phenylketonuria. Fakultas Kedokteran. Universitas Hasanuddin.

10. Montgomery AJ, McTavish SF, Cowen PJ, Grasby PM. (2014). Reduction of Brain Dopamine Concentration with Dietary Tyrosine Plus Phenylalanine Depletion: an (11C) Radopride PET Study. Am J Psychiatry. 160(10):1887-1889

11. Musacchio JM. (2013). Enzymes Involved in The Biosynthesis and Degradation of Catecholamines. In Iverson L. Biochemistry of Biogenic Amines. Springer.

12. The National Collaborating Centre for Chronic Conditions, ed. (2006). Symptomatic Pharmacological Therapy in Parkinson's Disease. Parkinson's Disease. London: Roy al College of Phy sicians

13. Petersen SE, Posner MI. (2012). The Attention System of The Human Brain: 20 Years After. Annu Rev Neurosci. 35: 73-89.

14. Kaluzka-Czaplinska J, Juzwik-Pruska J, Chirumbulo S, Bjorklund G. (2017). Tryptophan Status in Autism Spectrum Disorder and The Influence of Supplementation on Its Level. Metab Brain Dis. 32(5): $1585-1593$

15. Hurt EA, Arnold LE, Lofthouse N. (2011). Dietary and Nutritional Treatments for AttentionDeficit/Hyperactivity Disorder: Current Research Ssupport and Recommendation for Practitioners. Current Psychiatry Report. 13(5): 323-32.

16. Markus CR. (2008). Dietary Amino Acids and Brain Serotonin Function Implication for Stress-Related Afective Changes. Neuromol Med. 10: 247-58 